\title{
DEVELOPING STUDENTS COMMUNICATIVE SKILLS IN EDUCATIONAL PROGRAMMES AT NON-LINGUISTIC FACULTIES
}

\author{
Rimma Druzhinina \\ Pskov State University, the Russian Federation
}

\begin{abstract}
The article addresses some issues of developing students' communicative skills in foreign language teaching at non-linguistic faculties. The conceptual framework of the study follows the mode of professional competence approach. The study focuses on utilizing the project technology potential in students communication training. The topicality of the study is confirmed by a notable lack of data on the project technology application beyond the scope of regular English classes at non-linguistic faculties. Thus the study offers some new insights into the effects of the extracurricular project technology application for developing students' communicative skills. Hence the aim of the study is to propose theoretical justification and methodological development of utilizing the extracurricular project technology potential as a means of facilitating students communication training in foreign language teaching. Following the aim we have examined the essence and characteristics of students' communicative activities in foreign language teaching within extracurricular project cases. We have identified students communicative interaction algorithms and stages. We have designed a program for students communication training within the extracurricular project activities and elaborated a model of students' communicative interaction backed by a collection of vocabulary and speech patterns. We have verified the findings gained from the study in our experimental practical work. Research and experience data obtained make it possible to identify the significance of extracurricular project activities in foreign language teaching for students communication training at non-linguistic faculties.
\end{abstract}

Keywords: a model of students' communicative interaction, communication training, extracurricular project activities, foreign language teaching, non-linguistic faculties, students extra-curricular events, students language clubs.

\section{Introduction}

Communication training is considered to be an important component in management education programs (Bavina, 2006; Denisova, 2004 and others). Foreign language teaching at faculties of management based on communicative activities can contribute to students communication training. A number of scientists concentrate their studies on students communication training in foreign language teaching yet they associate it with language classroom teaching only (Abdrahmanova, 2007; Gorbunova, 2008 and others). However, the time 
Druzhinina, 2020. Developing Students Communicative Skills in Educational Programmes at Non-Linguistic Faculties

for language study is likely to be limited within a rigid timescale at nonlinguistic faculties. To solve the problem we propose ways of utilizing the reserves of extra-curricular activities in foreign language teaching.

Using the term "extra-curricular activities", as well as "students' extracurricular activities" we identify this phenomenon as a part of a university educational process, as a set of elevating, practice-oriented significant events implemented in students' and teachers' cooperation and aimed at students professional development in addition to regular classes and in connection with them. In our work the concept of students' extra-curricular activities in teaching a foreign language is implemented in students language clubs at faculties of management within conducting mass multi-component students events in a foreign language, i.e. carrying out extra-curricular projects.

Project technologies have been developed in education since the beginning of the $20^{\text {th }}$ century (Bespal'ko, 1995; Polat, 2000; Kolechenko, 2001 and others). There are numerous recommendations as to their structure, components and characteristics. In foreign language teaching a large number of scientists focus their research on project technologies but they prefer to work on areas of classroom language teaching and students' extra-curricular project activities in foreign language teaching is an area most often neglected by them (Golikova, 2005; Zemlinskaja, 2006; Voronina, 2010; Cyganova 2011 and others).

Hence the topicality of our study consists in:

- insufficient number of scientific works on extra-curricular project activities in foreign language teaching as a means of students communication training at faculties of management;

- insufficient application of extra-curricular project activities in foreign language teaching as a means of facilitating students' communicative potential.

Hence the purpose of our study is to develop and justify a concept of extracurricular project activities in foreign language teaching as a means of facilitating students communication training at faculties of management. The object of our study is the process of organizing students' extra-curricular project activities in foreign language teaching (FLT) at faculties of management. The subject of our study is a concept of students' extra-curricular project activities in FLT as a means of facilitating students communication training at faculties of management.

The tasks of our study consist in:

- examining components and characteristics of students' extracurricular project activities in FLT;

- modeling a scheme for students' extra-curricular activities in FLT within a project framework; 
- $\quad$ approbating the proposed model of extra-curricular project activities in FLT as a means of facilitating students communication training at faculties of management.

\section{Methodology}

The following research methods have been applied in our study: scientific literature analysis, work experience analysis, pedagogical observation, data analysis.

\section{Project technologies and communication training programs}

Methodologists in their research consider concepts of communicative activities which involve making use of the communicative competence while solving communication tasks. In our work we also identify students' communicative activities within an extra-curricular project as a means of developing their communicative competence and competencies.

Projects in education according to methodologists should combine students' independent work with their group exercises, as a result of which they should create a product of their activities. Project technologies are understood as a combination of teaching techniques, where the project itself plays the key role (Fried-Booth, 1986; Hutchinson, 1991; Golikova, 2005; Zemlinskaja, 2006; Cyganova, 2011). Projects are considered to be extremely fruitful for English conversation groups provided that only English is spoken during a given activity. Numerous task-based projects are available to teachers to involve the students in real-world activities that will expose them to a large amount of authentic language. Students advance through stages of the project, collecting data, reporting and analyzing results while developing their communicative skills in their group work (Dobson, 1992; Ellis \& Johnson, 1996). Possibilities for projects in extra-curricular activities in FLT are almost limitless: plays, shows, contests, debates.

In our work the activities in the students language club within a project are divided into several main stages: 1) diagnosing, 2) organizing, 3) developing, 4) approbating, 5) debriefing. Students' foreign language communicative activities and interaction occur at each stage as a separate communicative event with a specific scenario, aimed at handling tasks (solving problems) and at creating the designated communicative product. The process itself is composed of separate fractions of students' communicative activities and interaction. Each of these fractions represents a repeated in time, organized in space, short-term, small in volume, subject specific scheme of students' communicative interaction. 
Druzhinina, 2020. Developing Students Communicative Skills in Educational Programmes at Non-Linguistic Faculties

In the works of researchers we find descriptions of modeling methods. Modeling is described as replicating objects and processes in small forms and artificially created conditions. A model is defined as a system of elements that reproduces certain aspects, relationships, functions (Levchenko, 2005). In pedagogy this method is used while modeling didactic tasks, situations, processes.

Similar models of the communicative interaction are considered by educators in the so-called training technologies in teaching management. Training technologies are understood as specially organized, time-based procedures for teaching communicative skills and as based on a system of relationships between goals, content, methods, means and forms of training (Bavina, 2006; Belenkova, 2010 and others). "Training” in management is a notion commonly used to refer to what adults receive in a company context (e.g. management training). In FLT one of the implications of "teaching" is that it involves giving information about the system of the language whereas "training" implies developing skills in using the language as a means of communication reflecting the emphasis on skills and performance (Ellis \& Johnson, 1996).

Training technologies possess characteristics inherent in any pedagogical technology, namely: the cyclical nature of actions, repeatability, reproducibility, logical sequences of actions, rationing of interaction. The overall training structure by that is composed of a combination of technological steps. Each technological step represents a model of the communicative interaction of its participants and consists of the following stages: 1) immersion, 2) mini-lectures, 3) exercises, 4) debriefing (Bavina, 2006).

In our work interaction models are proposed as units of students' communicative activities in the program of an extra-curricular project. They should include the following components: 1) students' research in the information sources, 2) their findings positioning and active listening, 3) their interaction algorithms in discussion groups, 4) their communicative product. Technological steps (models) within the project are aimed at organizing students' communicative interaction and at developing their communicative skills. Each technological step should be designed in accordance with the goals and objectives of the overall project and be consistent with the form and methods of students group activities.

The goal of the program is to improve the students' communicative skills within their communicative interaction. In scientific literature many course books in FLT present a generally accepted common core of functions, structures and vocabulary for language class teaching but there are few descriptions of what a program (a course) of students' extra-curricular activities in FLT might consist of (Shepeleva, 1977; Savina, 1991). The overall extra-curricular project program in our case consists of a set of technological steps. The similarity of the 
structure of each technological step ensures technological cyclicality of the program.

Each technological step is based on implementing the prescribed rules (e.g. the "five facts" rule, the rule of information relevance, the rule of effective presentation of materials, the rule of short sentences, the rule of simple vocabulary units) for students to maintain their communication.

The first stage of each technological step may involve the situation analysis, students' pursuit for information, results forecasting. Information materials will be offered by students as based on the following principles:

- the optimal amount (no less and no more than it is required to solve the problem);

- relevance of information (not to deviate from handling the task);

- effective presentation (organization, clarity, uniqueness).

Students' pursuit for information may involve such operations as identifying, filtering, reviewing, combining, shortening, replacing, reconstructing, scaling, sequencing, adding, selecting, transferring, tailoring, editing. The information may be presented in various forms: fact graphs, story collages, grading schemes, diagrams of ideas, maps of actions. It may be also presented as print, audio, video, illustration materials. The information has to be conveyed with minimum risk of misunderstanding and the time for processing (both by the speaker and the listener) needs to be short. There is always a need to be concise. Therefore there is a preference for clear logical thought emphasized by the kind of words that indicate the logical process (e.g. "for this reason", "as a result", etc).

The second stage may involve such a task as "Reflexive interventions" (clarifying with questions). Within the information positioning such tasks as "Schemes", "Forms", "Geometric shapes" (creating a set of ideas for implementing the project) are used.

At this stage each discussion group of three students, for example, will handle the topic for at least 10 minutes to outline important points. One student in the group will be assigned to write down the points as they emerge from the discussion. The spokesman from each group will report on the group collective thoughts. He will summarize the selection and describe the group's reaction to it. The club members will question him or anyone else in his group on points expressed. The procedure continues until all the groups have given their presentations based on their research.

The third stage may involve such a task as "Enquiries and offers", where the group of "innovators" offers brief messages, the group of "pessimists" reveals weaknesses, the group of "optimists" argues for strong points, the group of "realists" suggests ways to use appropriate items to implement the idea. 
Druzhinina, 2020. Developing Students Communicative Skills in Educational Programmes at Non-Linguistic Faculties

In some papers we find descriptions of certain didactic structures, activities schemes which are called frameworks. Frameworks are usually diagrammatic representations which can be used to encourage interaction, to build conversations, to generate language, to guide learners in expressing ideas, describing situations, giving explanations. Frameworks are easy to produce. They can be drawn on the board or on a sheet of paper or on cards for handing out to learners. There are usually few words involved. Frameworks help learners to focus on the message to be conveyed according to established sequences.

Table 1 shows an example of a framework where students practice the language of alternative opinions.

Table 1 Balancing viewpoints framework (Ellis \& Johnson, 1996)

\begin{tabular}{|l|l|}
\hline $\begin{array}{l}\text { Learner } 1 \text { makes a statement about the topic } \\
\text { then chooses a second learner and asks for } \\
\text { his or her support }\end{array}$ & \\
\hline & $\begin{array}{l}\text { Learner } 2 \text { is unable to support Learner } 1 \text { and } \\
\text { makes an alternative comment, giving a } \\
\text { reason. Learner } 2 \text { then asks a third learner } \\
\text { for support }\end{array}$ \\
\hline $\begin{array}{l}\text { Learner } 3 \text { sees good reason to support } \\
\text { Learner } 1 \text { then asks Learner } 4 \text { for support. }\end{array}$ & $\begin{array}{l}\text { Learner } 4 \text { sees good reason to support } \\
\text { Learner } 2 \text { and asks Learner } 5 \text { for support }\end{array}$ \\
\hline $\begin{array}{l}\text { Learner } 5 \text { sees good arguments for both } \\
\text { Learners } 1 \text { and } 2 \text { and goes back to Learner } 1 \\
\text { for a comment, or moves on to Learner } 6\end{array}$ & \\
\hline
\end{tabular}

The fourth stage may involve 3-5 guidelines developed by the students within their communicative interaction. They will fix the most significant findings and rank them using various forms (e.g. "Required", "Desirable", "Maybe", "Memo for managers"). The stage may also involve the task "Packing the suitcase" where each participant goes to the center and verbalizes ("puts" into a simulated suitcase) what has been accumulated within the interaction.

Observing the students' communicative interaction at the first and the second stages we usually noted their attempts to use active listening, targeted clarifying questions, language tools for attracting attention.

Observing students' interaction at the third and the fourth stages we usually noticed their attempts to ask targeted and clarifying questions, to process objections, to reason statements.

The basic fabric of our program should be tasks (problems). The problem here may arise from the novelty of the content or the novelty of the presentation. It may also be provided by a lack of completeness of the information or its 
inconsistency. The tasks must have their specific objectives which should be clearly defined at the outset and which should relate to the overall objectives of the project. The task is the core of the model and, depending on the stage of the project, may include any of the following: creating an idea, supporting and opposing, coordinating positions, reviewing and concluding.

Table 2 Some target communication related vocabulary items within a group discussion (selected for the students language club in the experiential learning)

\begin{tabular}{|c|c|}
\hline Functional areas & Vocabulary items \\
\hline Giving Neutral Opinions & $\begin{array}{l}\text { I think that... } \\
\text { In my opinion ... / It's my opinion that... } \\
\text { As I see it... } \\
\text { As far as I'm concerned ... } \\
\text { From my point of view ... }\end{array}$ \\
\hline Giving Tentative Opinions & $\begin{array}{l}\text { It seems to me that... } \\
\text { I would say that... } \\
\text { As far as I'm able to judge ... } \\
\text { I think it would be fair to say that... }\end{array}$ \\
\hline Neutral Disagreement & $\begin{array}{l}\text { I'm afraid... } \\
\text { I'm sorry,... } \\
\text { I respect your opinion, of course, however... }\end{array}$ \\
\hline Partial Disagreement & $\begin{array}{l}\text { I don't completely agree with you on that. } \\
\text { I really can't agree with you on that. } \\
\text { I can't say that I share your view. } \\
\text { I can't accept your point of view. } \\
\text { I feel I must disagree. }\end{array}$ \\
\hline Neutral Agreement & $\begin{array}{l}\text { I agree. } \\
\text { I think we are in agreement on that. } \\
\text { I think you're right. } \\
\text { I think we can accept your position on that. }\end{array}$ \\
\hline Partial Agreement & $\begin{array}{l}\text { I would tend to agree with you on that. } \\
\text { I agree with you on the whole, but it could be said that... } \\
\text { I agree in principle, but... } \\
\text { By and large I would accept your views, but... }\end{array}$ \\
\hline Strong Agreement & $\begin{array}{l}\text { I completely agree. } \\
\text { I agree entirely with your point of view. } \\
\text { I'm of exactly the same opinion. } \\
\text { I am in total agreement. }\end{array}$ \\
\hline Tactful Disagreement & $\begin{array}{l}\text { I agree up to a point, but... } \\
\text { To a certain extent I agree with you, but... } \\
\text { I can see your point of view, but... }\end{array}$ \\
\hline
\end{tabular}

Handling tasks (solving problems) is associated not only with obtaining a communicative product but also with generating speech. The following typical performance areas will be important here: structure, process, function, cause, 
Druzhinina, 2020. Developing Students Communicative Skills in Educational Programmes at Non-Linguistic Faculties

effect, advantage, etc. As researchers state, the following language is important for cooperation: clarifying, checking, asking for explanations, restating, confirming, concluding (Ellis \& Johnson, 1996).

For each performance area a checklist of the key functions and selected language will be given.

\section{Experiential Learning}

In the field of management training nowadays there has been a move towards experiential learning (known as EXL), where learners develop their skills through active participation in tasks (e.g. Clark \& White, 2010 and others). EXL is a process of learning through experience. It entails a hands-on approach to learning that moves away from the teacher (imparting his knowledge) towards the students engaged in situated learning beyond the classroom (Kolb, 1984; Moon, 2004 and others).

Experiential learning in our study was conducted at Faculty of Management at Pskov State University over a period of September 2017-May 2018. There were engaged 24 students: the experimental group (members of the students language club) and the control group (their counterparts in regular classes). Within the period of the experiential learning the club participants were involved in developing students extra-curricular project in FLT (extra-curricular students debates (in English) on assigned topics at various faculties at Pskov State University).

The proposed model for developing students' communicative skills was approbated within the students extra-curricular project work. In our research we chose basic communicative skills, namely speaking and listening skills. We chose the following performance areas characteristic for them: active listening, clarifying, information positioning, attracting attention.

To measure the model feasibility a quantitative assessment criterion was selected with regard to the students' utterances (maintaining communication over a period of time) and their range of communication related vocabulary (the number of the vocabulary items): recycling target communication related language in students communicative interaction. To measure the number of the target communication related vocabulary items in students interaction (while performing communicative tasks in English) there were elaborated testing materials containing frameworks for students communicative interaction (e.g. Table 1).

Students interaction sessions were observed, recorded and the data were processed in the beginning and in the end of the experiential learning period.

The results gained are reflected in Table 3 and in Figure 1. 
Table 3 Recycling target communication related language in the control and experimental groups (average number of vocabulary items cases per student)

\begin{tabular}{|c|c|c|c|c|c|}
\hline \multicolumn{2}{|c|}{$\begin{array}{c}\text { Control group (average } \\
\text { number of cases per } \\
\text { student) }\end{array}$} & \multicolumn{2}{|c|}{$\begin{array}{c}\text { Experimental group } \\
\text { (average number of cases } \\
\text { per student) }\end{array}$} & $\begin{array}{c}\text { Dynamics from pre-experiment to } \\
\text { post-experiment testing (average } \\
\text { number of cases per student) }\end{array}$ \\
\hline Pre- & Post- & Pre- & Post- & CG & EG \\
\hline 4,1 & 10,5 & 6,4 & 20,6 & 6,4 & 14,2 \\
\hline
\end{tabular}

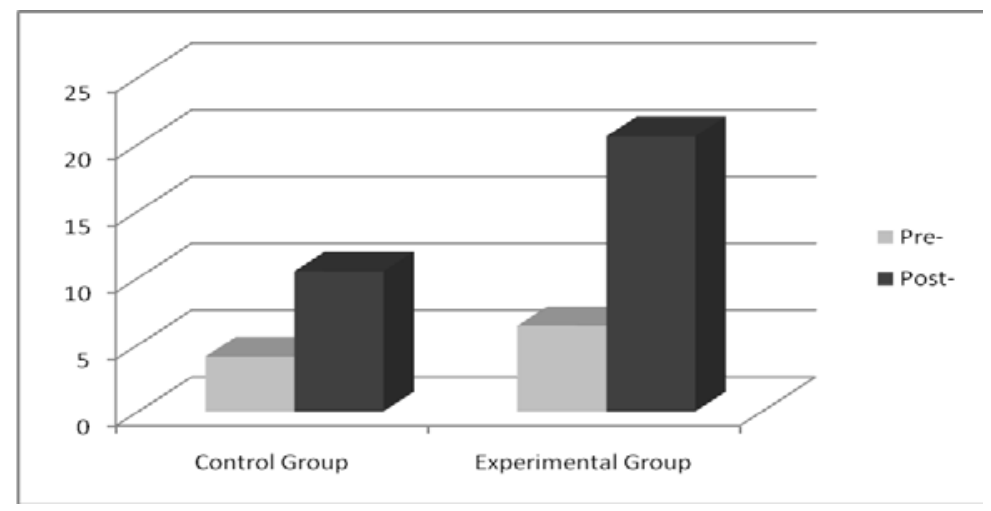

Figure 1 Dynamics in recycling target communication related language in the control and experimental groups (average number of vocabulary items cases per student)

The data obtained demonstrate higher increment in the number of the recycled vocabulary items in students communicative interaction in the experimental group as compared to the control group which gives evidence as to the feasibility of the proposed model for developing students' communicative skills.

On the whole, in the beginning of the semester we noted that the students in both groups could survive in the communication and were reasonably easy to understand, but had a lot of hesitancy, sometimes had to talk around the idea, had noticeable lapses in accuracy and organization of their speech.

In the end of the semester it could be seen that having attended the project sessions the students of the experimental group could argue more successfully for and against the case. Their communication and comprehension were more effective on most occasions. They could handle longer periods of interaction. Nevertheless they still had some way to go to improve the accuracy of structure and vocabulary.

Thus having performed in the extra-curricular project activities, the students, on the whole, contributed to the development of their communicative skills. They demonstrated a clearer delivery and a stronger confidence in speaking than their counterparts in the control group. 
Druzhinina, 2020. Developing Students Communicative Skills in Educational Programmes at Non-Linguistic Faculties

\section{Conclusions}

Thus in our study we have considered a concept of extra-curricular project activities in foreign language teaching as a means of facilitating students communication training at faculties of management. We have examined components and characteristics of students' extra-curricular project activities in foreign language teaching.

We have given some pointers about how to deal in students' extracurricular project activities in foreign language teaching. We have produced a model for students communicative interaction and identified its algorithms. We have offered some guidance as to how to design a communication training program within an extra-curricular project which includes tasks (problems), interaction frameworks, communication related target vocabulary bank. We have designed some frameworks for building conversations and generating targeted vocabulary. We have elaborated a list of recommendations for students to maintain their communication over a period of time. Thus we have provided some strategies for students communication training within an extra-curricular project in foreign language teaching.

We have approbated the proposed model as a means of facilitating students communication training at faculties of management. The data obtained in the experiential learning period demonstrated positive dynamics in the students' communicative skills development within the extra-curricular project in foreign language teaching. Thus we have found evidence that students' extra-curricular projects in foreign language teaching based on various communicative activities can facilitate students communication training at faculties of management.

\section{References}

Abdrahmanova, L.V. (2007). Formirovanie kommunikativnyh umenij u studentov tehnicheskogo vuza $v$ processe realizacii professional'no-diskussionnoj igrovoj tehnologii: na primere predmetnoj oblasti "Inostrannyj jazyk": dis. ... kand. pedagogicheskih nauk. Samara, Rossija: Abdrahmanova, L.V.

Bavina, P.A. (2006). Treningovye tehnologii v formirovanii kommunikativnoj kompetentnosti budushhih menedzherov: dis. ... kand. pedagogicheskih nauk. Sankt-Peterburg, Rossija: Bavina, P.A.

Clark, J., \& White, G. (2010). Experiential Learning: A Definitive Edge In The Job Market. American Journal of Business Education, 3(2), 115-118.

Cyganova, L.V. (2011). Formirovanie strategij samostojatel'noj raboty budushhih menedzherov sredstvami proektnoj tehnologii: dis. ... kand. pedagogicheskih nauk. Tol'jatti, Rossija: Cyganova, L.V.

Denisova, A.L. (2004). Metodologicheskie problemy podgotovki sovremennogo menedzhera $v$ innovacionnoj obrazovatel'noj srede: teoreticheskie aspekty i praktika. Samara, Rossija: Izd-vo SGJeA. 
Dobson, J.M. (1992). Effective Techniques for English Conversation Groups. Washington, DC: US Information Agency.

Ellis, M., \& Johnson, Ch. (1996). Teaching Business English. Oxford, UK: Oxford University Press.

Fried-Booth, D.L. (1986). Project work. New York: Oxford University Press.

Golikova, L.V. (2005). Formirovanie professional'noj inojazychnoj kommunikativnoj kompetentnosti studentov nejazykovogo vuza na osnove proektnoj tehnologii obuchenija: dis. ... kand. pedagogicheskih nauk. Sankt-Peterburg, Rossija: Golikova, L.V.

Gorbunova, I.P. (2008) Formirovanie kommunikativnoj kompetentnosti u budushhih menedzherov $v$ processe prepodavanija inostrannogo jazyka $v$ sisteme srednego professional'nogo obrazovanija: dis. ... kand. pedagogicheskih nauk. Cheboksary, Rossija: Gorbunova, I.P.

Hutchinson, T. (1991). Introduction to Project Work. Oxford: Oxford University Press.

Kolb, D. (1984). Experiential Learning: experience as the source of learning and development. Englewood Cliffs, NJ: Prentice Hall.

Levchenko, O.J. (2005). Obuchenie inojazychnomu professional'no-znachimomu dialogicheskomu obshheniju na osnove autentichnyh social'nyh kontaktov (anglijskij jazyk, nejazykovyj vuz): dis. ... kand. pedagogicheskih nauk. Irkutsk, Rossija: Levchenko, O.J.

Moon, J. (2004). A Handbook of Reflective and Experiential Learning: Theory and Practice. London: Routledge Falmer.

Savina, S.N. Vneklassnaja rabota po inostrannym jazykam v srednej shkole. Moskva, Rossija: Prosveshhenie.

Shepeleva, V.I. (1977). Vneurochnaja rabota po nemeckomu jazyku: Posobie dlja uchitelja srednej shkoly. Moskva, Rossija: Prosveshhenie.

Zemlinskaja, T.E. (2006). Formirovanie samoobrazovatel'noj kompetentnosti studentov tehnicheskih vuzov na osnove proektnoj tehnologii: na materiale obuchenija inostrannomu jazyku: dis. ... kand. pedagogicheskih nauk. Sankt-Peterburg, Rossija: Zemlinskaja, T.E. 